\title{
STUDI ANTIDIABETES KOMBINASI EKSTRAK ETANOL KUBIS (Brassica oleracea L.) DAN TOMAT (Solanum lycopersicum L.) SECARA IN VITRO
}

\author{
Devina Ingrid Anggraini, Dwi Damayanti \\ Program Studi D3 Farmasi, Sekolah Tinggi IImu Kesehatan (STIKES) Nasional Surakarta \\ Email: devina.ia@gmail.com
}

\begin{abstract}
Diabetes mellitus is a health problem in the world including Indonesia. A lot of treatment efforts to control and lowering blood sugar levels done with drugs hypoglycemic of natural materials. This research was conduct to determine the combination of extract cabbage (Brassica oleracea L.) and tomato (Solanum lycopersicum L.) have activity antidiabetic and more effective than extract single. Study performed on four comparison concentration sample extract ethanol cabbage and tomato are 1:0;2:1;1:2 and 0:1. Method wich is use in this study the method of Nelson-Somogyi by using the instrument spectrophotometer UV-Vis. Decline glucose levels highest obtained in the concentration of extract cabbage and tomato with the ratio of 1:2 is 4,5165 ppm and decrease in glucose levels lowest obtained in the concentration of extract cabbage and tomato with the ratio of 1 : 0 is $5,1613 \mathrm{ppm}$.
\end{abstract}

Key Words : Methods Nelson-Somogyi, Cabbage, Tomato, EC $_{50}$.

\section{PENDAHULUAN}

Penyakit diabetes mellitus (DM) merupakan suatu gangguan dari sistem metabolisme yang ditandai oleh hiperglikemia maupun abnormalitas dalam metabolisme karbohidrat, lemak, dan protein. Hal tersebut terjadi karena penurunan sekresi insulin, penurunan sensitivitas insulin, ataupun keduanya. $^{1} \quad$ Diabetes melitus merupakan masalah kesehatan di seluruh dunia termasuk Indonesia. World Health Organization (WHO) menyebutkan bahwa estimasi jumLah pasien diabetes di seluruh dunia tahun 2015 sebanyak 415 juta jiwa dan tahun 2040 sebanyak 642 juta jiwa. Angka kejadian DM di Indonesia dari tahun ke tahun juga meningkat. Berdasarkan data dari Riskesdas prevalensi diabetes di Indonesia meningkat dari 5,7\% pada tahun 2007 dan $6,9 \%$ pada tahun $2016{ }^{2}$

Berbagai upaya pengobatan untuk mengontrol dan menurunkan kadar gula darah dilakukan dengan menggunakan obat sintetik maupun obat-obatan yang berasal dari bahan alam. Indonesia merupakan negara yang memiliki keanekaragaman jenis flora, yang dapat berpotensi digunakan sebagai tanaman obat. Bahan alam tersebut banyak digunakan untuk pengobatan maupun pencegahan dari suatu penyakit. Hal tersebut dianggap lebih aman dibanding bahan kimia yang beredar dipasaran. Oleh karena itu kesadaran masyarakat untuk menjaga kesehatannya dengan meningkatkan konsumsi sayur dan buah baik dengan pengolahan maupun dikonsumsi secara langsung.

Salah satu sayur yang banyak dikonsumsi oleh masyarakat adalah kubis. Kubis merupakan bahan pangan yang harganya relatif murah, bergizi, dan mudah didapat. Hasil penelitian Anggie melaporkan bahwa penapisan fitokimia ekstrak kubis putih mengandung flavonoid dan triterpenoid. ${ }^{3}$ Kandungan kimia yang terkandung pada ekstrak etanol kubis yaitu alkaloid, saponin, dan glikosida. Uji penghambatan aktivitas $\alpha$ glukosidase oleh kubis dilaporkan memiliki 
Studi antidiabetes kombinasi ekstrak etanol kubis (Brassica oleracea L.) dan tomat (Solanum lycopersicum L.) secara in vitro

nilai $I_{50} \quad 439,38$ ppm dan memiliki efek antidiabetes yang berasal dari beberapa senyawa yang terkandung didalamnya. ${ }^{1}$

Selain kubis, ternyata tomat juga dipercaya mampu menurunkan kadar gula darah, menurunkan kadar kolesterol, menghambat penurunan kadar hormon testosteron. ${ }^{4}$ Senyawa yang terkandung dalam tomat yaitu fenolat, flavonoid, dan likopen. Ekstrak metanol buah tomat dilaporkan memiliki aktivitas antioksidan dengan $\mathrm{IC}_{50}$ $44,06 \mu \mathrm{g} / \mathrm{mL} .{ }^{5} \mathrm{Hal}$ ini didukung oleh penelitian Widowati yang mendapatkan bahwa senyawa antioksidan sintetik maupun alami (dari berbagai tanaman) mampu mengontrol kadar glukosa darah dan mencegah komplikasi diabetes. $^{6}$

Kombinasi dari beberapa bahan alam diharapkan dapat meningkatkan potensi antidiabetes seperti penelitian yang dilaporkan oleh Yusni, et al., menunjukkan bahwa pemberian kombinasi ekstrak kulit manggis dan tomat dosis $50 \mathrm{mg} / \mathrm{kgBB} /$ hari menurunkan kadar glukosa dalam darah tikus putih (Rattus norvegicus) jantan diabetes dan berpotensi untuk dikembangkan sebagai obat antidiabetes. ${ }^{4}$ Penelitian lain menyebutkan bahwa kombinasi jus kacang panjang dan jus tomat dengan dosis $12 \mathrm{~g} / \mathrm{kgBB}$ mencit serta kombinasi jus kacang panjang dan tomat dengan dosis (1:1) 24g/kgBB mencit memiliki efek antihiperglikemia, ditandai dengan ratarata penurunan kadar glukosa darah yaitu jus kacang panjang sebesar $264,72 \mathrm{mg} / \mathrm{dL}$, tomat $141,33 \mathrm{mg} / \mathrm{dL}$, dan kombinasi $116,33 \mathrm{mg} / \mathrm{dL}^{7}$

Studi tentang antidiabetes kombinasi bahan alam diperlukan untuk mencari sumber baru yang berpotensi dalam pengobatan diabetes melitus. Berdasarkan uraian diatas maka perlu dilakukan penelitian guna meningkatkan peran bahan alam sebagai agen antidiabetes.

\section{METODE PENELITIAN}

\section{Alat dan Bahan}

Alat-alat yang digunakan pada penelitian ini adalah Spektofotometer UV-Vis (Shimadzu UV mini-1240), kuvet Hellma Analytic type No 100.600 QG Light parh lotum, rotary evaporator, neraca analitik (Ohaus Pioneer dengan sensitivitas $0,0001 \mathrm{~g}$ dan minimal penimbangan $0,1000 \mathrm{~g}$ ), alat-alat gelas seperti beaker glass, labu ukur dan tabung reaksi (pyrex), oven, blender, pipet volume, mikropipet, push ball. Selain itu digunakan pula alat-alat penunjang yang lazim digunakan dalam analisis spektrofotometri. Bahan yang digunakaan dalam penelitian ini adalah sayur kubis (Brassica oleracea L.) dan buah tomat (Solanum lycopersicum L.) yang diperoleh dari Dusun Gunungsari Desa Senden Kecamatan Selo Kabupaten Boyolali, etanol 96\%, pereaksi Nelson, reagen arsenomolibdat, glukosa p.a, $\mathrm{HCl} 2 \mathrm{~N}$, reagen Mayer, reagen Wagner, reagen Dragendorff, $\mathrm{HCl}$ pekat, serbuk seng, serbuk Mg, kloroform, $\mathrm{H}_{2} \mathrm{SO}_{4}$ pekat, $\mathrm{CH}_{3} \mathrm{COOH}$ glasial, $\mathrm{FeCl}_{3} 1 \%$, aquadest.

\section{Prosedur Kerja}

\section{Determinasi tanaman}

Identifikasi kubis (Brassica oleracea L.) dan buah tomat (Solanum lycopersicum L.) dilakukan di Balai Besar Penelitian dan Pengembangan Tanaman Obat dan Obat Tradisional Tawangmangu.

\section{Pembuatan Simplisia}

Bahan baku sayur kubis dan buah tomat disortasi basah dengan memilih bagian tanaman yang akan digunakan untuk pengujian Perajangan dilakukan untuk mempercepat proses pengeringan. 
Studi antidiabetes kombinasi ekstrak etanol kubis (Brassica oleracea L.) dan tomat (Solanum lycopersicum L.) secara in vitro

Pembuatan serbuk dilakukan dengan menggunakan blender dan diayak dengan ayakan mesh 40.

\section{Ekstraksi Simplisia}

Serbuk simplisia kubis dan tomat masing-masing ditimbang sebanyak sebanyak 100 gram. Maserasi dilakukan dengan pelarut etanol $96 \%$ sebanyak $(1: 7,5)$ selama 3 hari dengan pengadukan setiap hari. Saring hingga diperoleh filtrat pertama. Residu yang didapat dilakukan penyarian kembali dengan cara yang sama selama 2 hari menggunakan pelarut baru (etanol 96\%) sebanyak (1:2,5) sehingga didapat filtrat kedua. Filtrat pertama dan kedua dicampur menjadi satu. Pekatkan dengan rotary evaporator suhu $40^{\circ}-60^{\circ} \mathrm{C}$ dan diuapkan di atas waterbath hingga diperoleh ekstrak kental. ${ }^{8}$

\section{Uji Fitokimia}

$\begin{array}{clcc}\text { Uji } & \text { fitokimia dilakukan untuk } \\ \text { mengetahui } & \text { kandungan senyawa yang }\end{array}$ terdapat didalam sampel kubis dan tomat serta berpotensi sebagai antidiabetes. Uji fitokimia yang dilakukan meliputi uji alkaloid, uji flavonoid, uji saponin, uji triterpenoid, dan uji tanin.

\section{Uji Potensi Antidiabetes}

Uji potensi antidiabetes dilakukan menggunakan spektrofotometri visibel dengan didahului penentuan panjang operating time (OT), scanning gelombang maksimum, pembuatan larutan kontrol positif, dan uji aktivitas antidiabetes. Penentuan operating time dilakukan dengan cara memipet sebanyak $0,5 \mathrm{~mL}$ dari larutan baku kerja glukosa p.a 80 ppm kemudian dimasukkan ke dalam tabung reaksi. Kemudian ditambahkan 1,0 $\mathrm{mL}$ reagen Nelson dan ditutup dengan kapas, kemudian dipanaskan di atas air mendidih selama 10 menit. Larutan didinginkan selama 5 menit lalu dipindahkan ke dalam labu ukur 5,0 mL secara kuantitatif, kemudian ditambahkan $1,0 \mathrm{~mL}$ reagen arsenomolibdat ke dalam labu tersebut lalu diencerkan dengan aquadest sampai batas, dikocok. Serapan diukur pada panjang gelombang maksimum teoritis $745 \mathrm{~nm}$ selama 40 menit dengan interval per menit, sehingga didapat waktu optimum yang stabil. ${ }^{9}$ Perlakuan yang sama dilakukan juga untuk scanning panjang gelombang maksimum dengan operating time selama waktu 25 menit. Hasilnya dibaca dengan spektrofotometer UVVis pada panjang gelombang $700-780 \mathrm{~nm}$.

Pembuatan larutan kontrol positif dilakukan dengan cara memipet sebanyak 1,0 $\mathrm{mL}$ dari larutan baku kerja glukosa p.a. 50 ppm kemudian ditambahkan $1,0 \mathrm{~mL}$ reagen Nelson dan ditutup dengan kapas, kemudian dipanaskan di atas air mendidih selama 10 menit. Larutan didinginkan selama 5 menit lalu dipindahkan ke dalam labu ukur 5,0 $\mathrm{mL}$ secara kuantitatif, kemudian ditambahkan 1,0 mL reagen arsenomolibdat ke dalam labu tersebut lalu diencerkan dengan aquadest sampai batas, dikocok. Kombinasi ekstrak kubis dan tomat dibuat perbandingan bobot ekstrak kental. Pembuatan kombinasi ekstrak sampel 1000 ppm dilakukan dengan cara memasukkan masing-masing kombinasi ekstrak ke dalam labu ukur 100,0 mL kemudian ditambah aquadest hingga tanda batas dan dikocok.

Uji antidiabetes dilakukan dengan mengetahui penurunan kadar glukosa setelah adanya perlakuan. Ekstrak etanol kubis dan tomat masing-masing dibuat seri konsentrasi 1, 2, 3, 4, dan 5 ppm ditambahkan 1,0 mL baku glukosa dari konsentrasi $50 \mathrm{ppm}$. Kemudian ditambahkan 1,0 mL reagen Nelson 
Studi antidiabetes kombinasi ekstrak etanol kubis (Brassica oleracea L.) dan tomat (Solanum lycopersicum L.) secara in vitro

dan ditutup dengan kapas, kemudian dipanaskan di atas air mendidih selama 10 menit. Larutan didinginkan selama 5 menit lalu dipindahkan ke dalam labu ukur $5,0 \mathrm{~mL}$ secara kuantitatif, kemudian ditambahkan $1,0 \mathrm{~mL}$ reagen arsenomolibdat ke dalam labu tersebut lalu diencerkan dengan aquadest sampai batas, dikocok dan didiamkan selama waktu 25 menit. Hasil dibaca dengan spektrofotometer UV-Vis pada panjang gelombang maksimal 748,1 nm kemudian dihitung persentase penurunan kadar glukosa.

\section{Analisis Data}

Absorbansi yang diperoleh dari pengukuran sampel kombinasi kubis dan tomat dibandingkan dengan larutan kontrol positif untuk mengetahui persen kadar penurunan kadar glukosa. Perhitungan persentase penurunan kadar glukosa menggunakan rumus berikut:

$$
A=\frac{C-B}{C} X 100 \%
$$

Keterangan :

$$
\begin{array}{ll}
\mathrm{A} & =\% \text { penurunan kadar glukosa } \\
\mathrm{B} & =\text { Absorbansi glukosa sisa } \\
\mathrm{C} & =\text { Absorbansi kontrol positif }
\end{array}
$$

\section{HASIL DAN PEMBAHASAN}

\section{Determinasi Tanaman}

Identifikasi kubis (Brassica oleracea

L.) dan buah tomat (Solanum lycopersicum L.) dilakukan untuk menghindari kesalahan dalam pengambilan tanaman serta memastikan dan mendapatkan kebenaran identitas dari tanaman yang akan diteliti. Identifikasi terhadap tanaman dilakukan di Balai Besar Penelitian dan Pengembangan Tanaman Obat dan Obat Tradisional Tawangmangu. Hasil identifikasi menunjukkan bahwa tanaman yang digunakan dalam penelitian ini benar kubis (Brassica oleracea L.) yang berasal dari familia Brassicaceae dan buah tomat
(Solanum lycopersicum L.) yang berasal dari familia Solanaceae.

\section{Ekstraksi Simplisia}

Ekstraksi serbuk simplisia dilakukan denga metode rmaserasi dengan menggunakan pelarut etanol 96\%. Metode maserasi dipilih karena metode yang sederhana dan diharapkan dapat menarik kandungan senyawa yang ada dalam simplisia lebih maksimal. Pemilihan pelarut juga merupakan tahap yang penting karena diharapkan dapat menyari semua kandungan zat aktif yang diuji. Etanol 96\% dipilih karena berdasarkan hasil penelitian Hamdani menunjukkan bahwa etanol $96 \%$ lebih efektif menurunkan kadar glukosa ekstrak umbi bawang dayak terbaik dibanding etanol $70 \%$ dan etanol $50 \% .{ }^{10}$ Hasil ekstraksi kubis dan tomat dengan pelarut etanol $96 \%$ berupa ekstrak kental berwarna coklat pekat.

\section{Uji Fitokimia}

Uji fitokimia dilakukan untuk mengetahui adanya kandungan metabolit sekunder yaitu alkaloid, flavonoid, triterpenoid, saponin, dan tanin yang terkandung dalam ekstrak etanol kubis dan tomat, sehingga dapat diketahui senyawa yang berpotensi sebagai antidiabetes. Tujuan dilakukan uji fitokimia pada ekstrak etanol kubis dan tomat yaitu untuk mengetahui pengaruh serangkaian proses ekstraksi terhadap kandungan senyawa kimia dalam sampel. Simplisia kubis dan tomat dilarutkan dengan etanol $96 \%$ yang mampu melarutkan senyawa-senyawa yang terkandung dan dapat bercampur dengan reagen-reagen untuk identifikasi senyawa. Ekstrak etanol kubis dan tomat menunjukkan hasil positif pada uji fitokimia senyawa golongan alkaloid, flavonoid dan triterpenoid. 
Studi antidiabetes kombinasi ekstrak etanol kubis (Brassica oleracea L.) dan tomat (Solanum lycopersicum L.) secara in vitro

\section{Uji Potensi Antidiabetes}

\section{Penentuan Operating Time (OT)}

Waktu operasional (operating time) digunakan untuk pengukuran hasil reaksi atau pembentukan warna. Tujuannya adalah untuk mengetahui waktu pengukuran yang stabil. Hasil penentuan operating time didapatkan absorbansi yang stabil pada menit ke 25-27 dengan absorbansi 0,541.

\section{Penentuan panjang gelombang maksimum}

Penentuan panjang gelombang maksimum dilakukan dengan tujuan mendapatkan serapan yang maksimum dari larutan. Pengujian dilakukan pada kisaran panjang gelombang 700-780 nm. Rentang tersebut dipilih karena secara teoritis panjang gelombang glukosa yaitu $745 \mathrm{~nm}$. Hasil pengukuran panjang gelombang maksimum dari glukosa 8 ppm diperoleh 748,1 nm dengan nilai absorbansi 0,533.

\section{Pembuatan kurva standar glukosa}

Kurva baku merupakan kurva yang menyatakan hubungan antara absorbansi dengan konsentrasi. Tujuan dilakukannya pembuatan kurva baku untuk mendapatkan persamaan linieritas antara absorbansi dan konsentrasi. Persamaan linier yang didapat dari kurva kalibrasi $y=0,099 x-0,210$ dengan nilai koefisien relasi $R^{2}=0,999$ yang berarti ada korelasi antara absorbansi dengan konsentrasi.

\section{Pembuatan larutan kontrol positif}

Absorbansi kontrol digunakan untuk menghitung \% penurunan kadar glukosa, sehingga dapat mengetahui banyaknya glukosa sisa yang tidak bereaksi dengan senyawa yang terkandung pada sampel. Semakin besar \% penurunan kadar glukosa maka potensi penurunan kadar glukosa juga semakin tinggi. Absorbansi rata-rata kontrol positif yang didapat yaitu 0,765 .

\section{Penentuan Penurunan Kadar Glukosa}

Uji aktivitas penurunan kadar glukosa dilakukan secara in vitro dengan menggunakan metode Nelson-Somogyi. Metode Nelson-Somogyi dipilih karena lebih spesifik jika digunakan dalam penetapan kadar gula pereduksi pada sampel yang memiliki senyawa gula campuran didalamnya. Perbandingan hasil uji validasi antara metode Nelson-Somogyi dan Anthrone-Sulfat menujukkan bahwa metode Nelson-Somogyi memiliki nilai kepekaan yang lebih tinggi sehingga lebih disarankan digunakan untuk menganalisa gula pereduksi. ${ }^{11}$

Penambahan reagen Nelson bertujuan untuk mereduksi kupri oksida menjadi kupro oksida yang mana K-Na-tartrat yang terkandung dalam reagen Nelson berfungsi untuk mencegah terjadinya pengendapan kupri oksida. Setelah ditambahkan reagen Nelson, larutan yang berwarna biru kehijauan tersebut dipanaskan 10 menit, tujuan dari pemanasan ini adalah untuk mempercepat proses reduksi kupri oksida menjadi kupro oksida. Selanjutnya larutan didinginkan supaya reaksi berjalan stabil, karena apabila terlalu panas kemungkinan akan ada komponen senyawa yang rusak atau menguap. Kemudian ditambahkan $1 \mathrm{~mL}$ reagen arsenomolibdat, penambahan reagen arsenomolibdat ini bertujuan agar bisa bereaksi dengan endapan kupro oksida. Pada peristiwa ini kupro oksida akan mereduksi kembali arsenomolibdat menjadi molibdene blue yang berwarna biru kehijauan yang nanti diukur absorbansinya dengan spektrofotometer. Reaksi glukosa dengan pereaksi nelson ditunjukkan pada gambar 1 . 
Studi antidiabetes kombinasi ekstrak etanol kubis (Brassica oleracea L.) dan tomat (Solanum lycopersicum L.) secara in vitro

Kemampuan ekstrak etanol kubis dan tomat dalam menurunkan kadar glukosa disebabkan adanya kandungan senyawa alkaloid, flavonoid, dan triterpenoid. Semakin besar kadar glukosa sisa yang terkandung dalam larutan sampel maka akan semakin pekat warna biru yang terbentuk. Semakin pekat warna biru maka cahaya yang diserap semakin banyak dan cahaya yang ditransmisikan semakin sedikit sehingga nilai absorbansi yang diperoleh ketika pengukuran akan semakin besar. Mekanisme reaksi antara flavonoid dan glukosa disajian pada gambar 2 .

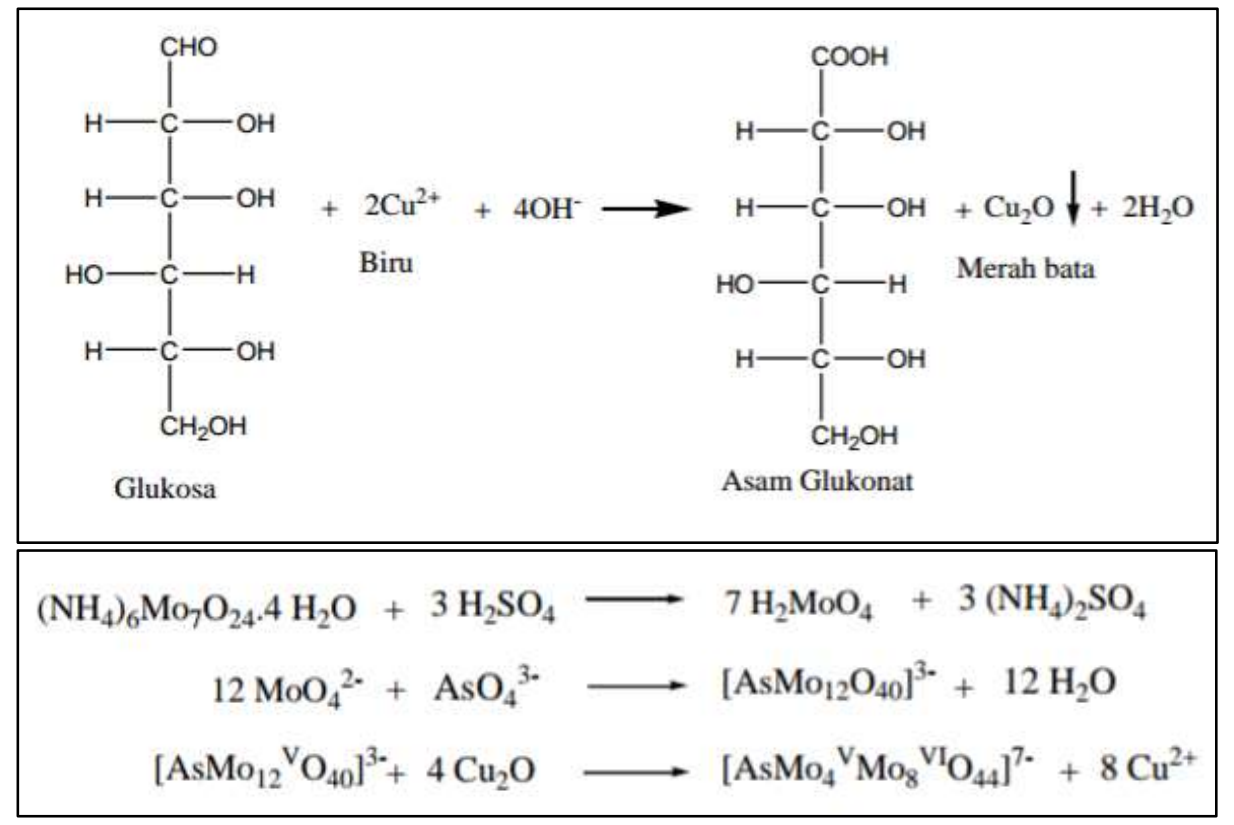

Gambar 1. Reaksi Glukosa dengan Pereaksi Nelson
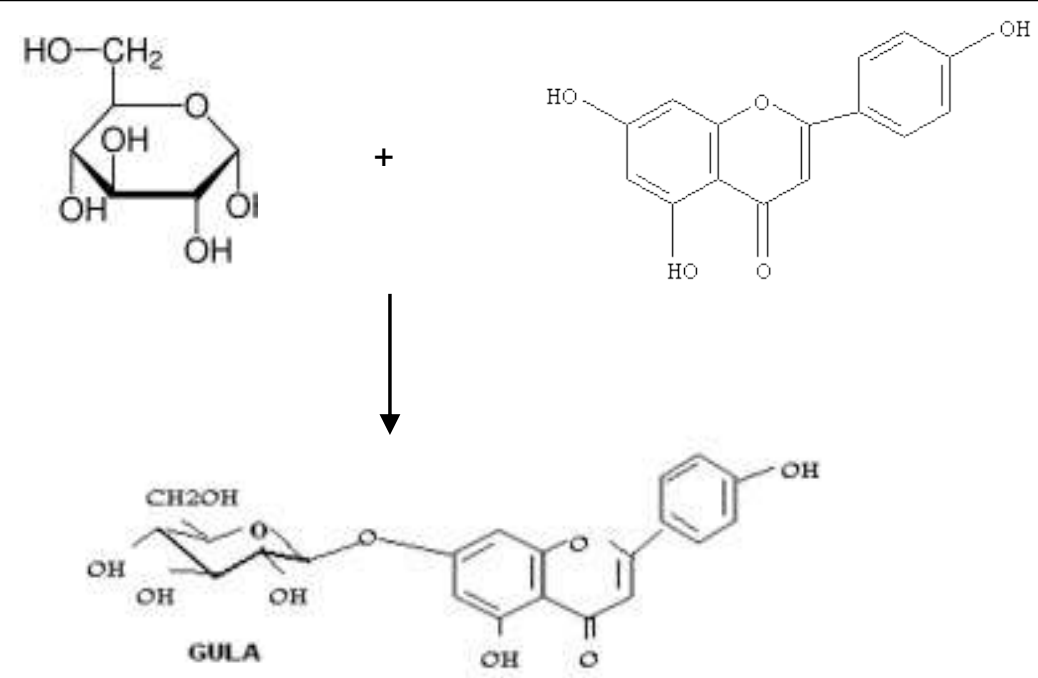

AGL.KOH

Gambar 2. Reaksi antara flavonoid dan glukosa 
Studi antidiabetes kombinasi ekstrak etanol kubis (Brassica oleracea L.) dan tomat (Solanum lycopersicum L.) secara in vitro

Reaksi yang terjadi menyebabkan gugus hidroksil flavonoid terikat pada satu gula atau lebih dengan ikatan hemiasetal yang tidak tahan asam. Glikosida yang terbentuk ini menyebabkan flavonoid lebih mudah larut dalam air.

Tabel 1 menunjukkan bahwa kombinasi ekstrak kubis dengan ekstrak tomat perbandingan (1:2) memiliki kemampuan menurunkan kadar glukosa terbaik dan berpotensi sebagai antidiabetes. Besarnya penurunan kadar glukosa ditandai dengan nilai $E_{50}$ yaitu suatu nilai yang menggambarkan besarnya konsentrasi larutan uji yang menghasilkan 50\% efek maksimal melalui persamaan garis regresi linier yang menyatakan hubungan antara konsentrasi larutan uji dengan \% penurunan kadar glukosa. Semakin kecil nilai $\mathrm{EC}_{50}$ menunjukkan bahwa penurunan kadar glukosa menggunakan sampel semakin besar, begitu juga sebaliknya.

Tabel 1. Nilai $\mathrm{EC}_{50}$ masing-masing kombinasi ekstrak etanol kubis dan tomat

\begin{tabular}{ccccc}
\hline Sampel & Triplo & Nilai $\mathbf{E C}_{50}(\mathbf{p p m})$ & $\% \mathbf{K V}$ & Rata-rata nilai $\mathbf{E C}_{50}(\mathbf{p p m})$ \\
\hline \multirow{2}{*}{ Kombinasi 1:0 } & 1 & 5,1608 & & \\
& 2 & 5,1921 & $0,5909 \%$ & 5,1613 \\
Kombinasi 2:1 & 3 & 5,1311 & & \\
& 1 & 4,7046 & & 4,7299 \\
Kombinasi 1:2 & 2 & 4,7561 & $0,5455 \%$ & \\
& 3 & 4,7291 & & 4,5165 \\
Kombinasi 0:1 & 1 & 4,5347 & & \\
& 2 & 4,4964 & $0,4251 \%$ & 4,8155 \\
\hline
\end{tabular}

Nilai \% KV atau presisi menunjukkan seberapa dekat suatu hasil pemeriksaan bila dilakukan berulang dengan sampel yang sama. Semakin kecil nilai \% KV menunjukkan kecermatan atau ketelitian yang semakin baik. Nilai \% KV dinyatakan baik apabila kurang dari $2 \%$. Hasil penelitian menunjukkan semua perbandingan konsentrasi memenuhi persyaratan presisi.

\section{KESIMPULAN}

Dari hasil peneitian yang telah dilakukan dapat diambil kesimpulan bahwa kombinasi ekstrak kubis dan tomat memiliki aktivitas antidiabetes.Kombinasi ekstrak kubis dan tomat perbandingan (1:2) memiliki penurunan kadar glukosa terbaik sebesar 4,5156 ppm dan berpotensi sebagai antidiabetes.

\section{DAFTAR PUSTAKA}

1. Febrinda $A E$, Astawan M, Wresdiyati $T$, Yuliana ND. Kapasitas antioksidan dan inhibitor alfa glukosidase ekstrak umbi bawang dayak. J Teknol dan Ind Pangan 2013;24(2):161.

2. Kesehatan K. Riset Kesehatan Dasar (Riskesdas). Kemenkes RI. 2013.

3. Anggie RD. Pengaruh suhu dan lama penyimpanan terhadap kadar flavonoid total dan aktivitas antioksidan ekstrak etanol kubis merah (Brassica oleracea Var. Capitata rubra) (Tesis). Semarang: Universitas Wahid Hasyim, 2018.

4. Yusni Y, Akbar IB, Rezania R, Fahlevi R. Penurunan kadar gula darah akibat pemberian ekstrak manggis (Garcinia mangostana) dan tomat (Lycopersicum esculentum Mill) pada tikus diabetes. Glob Med Health Commun 2017;5(1):57-63.

5. Regina A, Maimunah M, Yovita L. Penentuan aktivitas antioksidan, kadar 
Studi antidiabetes kombinasi ekstrak etanol kubis (Brassica oleracea L.) dan tomat (Solanum lycopersicum L.) secara in vitro

fenolat total dan likopen pada buah tomat (Solanum lycopersicum L.). J Sains Dan Teknol Farm 2008;13(1).

6. Widowati W. Potensi antioksidan sebagai antidiabetes. Maranatha J Med Health. $2008 ; 7(2)$.

7. Cahyani DN. Uji aktivitas antihiperglikemia kombinasi jus kacang panjang (Vigna unguiculata L. Walp) dan jus tomat (Solanum lycopersicum L.) pada mencit swiss webster jantan dengan metode induksi aloksan (Skripsi). Bandung: Universitas Ilam Bandung, 2015.

8. Meila $\mathrm{O}$, Noraini N. Uji aktivitas antidiabetes dari ekstrak metanol buah kiwi (Actinidia deliciosa) melalui penghambatan aktivitas a-Glukosidase. J Farm Galen Galen J Pharm 2017;3(2):132-137.
9. Aprizayansyah A, Wiendarlina IY, Wardatun S. Aktivitas penurunan kadar glukosa ekstrak daun sukun (Artocarpus altilis (Park.) Fosberg) secara in vitro dan korelasinya terhadap kandungan flavonoid. Bogor: Universitas Pakuan, 2015.

10. Hamdani LS, Wardatun S, Miranti M. Aktivitas penurunan kadar gula dan potensi antioksidan ekstrak umbi bawang dayak (Eleutherine palmifolia (L.) Merr). Bogor: Universitas Pakuan.

11. Al-kayyis HK, Susanti H. Perbandingan metode somogyi-nelson dan anthronesulfat pada penetapan kadar gula pereduksi dalam umbi cilembu (Ipomea batatas L.). J Farm Sains dan Komunitas J Pharm Sci Community. 2016;13(2):81-89. 